\title{
Effects of formaldehyde preservation time on the length- weight relationship of the ubiquitous neotropical cladoceran Ceriodaphnia silvestrii
}

Efeito do tempo de preservação por formaldeído na relação peso-comprimento do ubíquo cladócero neotropical Ceriodaphnia silvestrii

\author{
Rafael Lacerda Macêdo ${ }^{1,3^{*}}$ (D), Lorena Pinheiro-Silva ${ }^{2}$ (D), Adriana Lamanna Puga ${ }^{1}$ (D), \\ Gabriel Klippel $^{1}$ (D), Betina Kozlowsky-Suzuki ${ }^{1}$ (D), Odete Rocha ${ }^{3}$ (D) and \\ Christina Wyss Castelo Branco ${ }^{1}$
}

${ }^{1}$ Núcleo de Estudos Limnológicos, Universidade Federal do Estado do Rio de Janeiro - UNIRIO, Av. Pasteur, 458, 22290-240, Rio de Janeiro, RJ, Brasil.

${ }^{2}$ Laboratório de Ecologia de Águas Continentais, Departamento de Ecologia e Zoologia, Universidade Federal de Santa Catarina, Campus Universitário Reitor João David Ferreira Lima, 88040-900 Florianópolis, Santa Catarina, Brasil.

${ }^{3}$ Departamento de Ecologia e Biologia Evolutiva - DEBE, Universidade Federal de São Carlos UFSCar, Rodovia Washington Luis, Km 235, 13565-905, São Carlos, SP, Brasil.

*e-mail: rafaell261@hotmail.com

Cite as: Macêdo, R.L. et al. Effects of formaldehyde preservation time on the length-weight relationship of the ubiquitous neotropical cladoceran Ceriodaphnia silvestrii. Acta Limnologica Brasiliensia, 2021, vol. 33, e27.

Abstract: Aim: In this study, the effect of preservation time on total body length and dry weight of adult specimens of the neotropical cladoceran Ceriodaphnia silvestrii preserved with $4 \%$ formalin solution were examined. Methods: The relationship between these variables was examined under increasing gradual time effects (i.e. 7, 30, and 60 days) after preservation using linear models and analysis of variance. Results: Total body length did not statistically differ between fresh and preserved cladocerans at any preservation time, whereas dry weight was drastically reduced with increasing preservation time, with 15, 47 and 57\% weight losses. Length-weight relationships were significantly and positively related in all treatments, though higher values of slope were found for fresh and 7 days samples. Conclusions: We highlight that, for Ceriodaphnia silvestrii, the use of the formalin solution as a preservation fixative is not adequate when the major interest is biomass estimation. Also, we recommend that dry weight estimations from preserved samples should be done as soon as possible. Finally, considering the preservation losses and intra-specific composition of organisms, the application of correction factors is advised since preserved samples are important in the evaluation of long-term changes of biological communities.

Keywords: body length; Daphnidae; dry weight; fresh weight; secondary productivity.

Resumo: Objetivo: Neste estudo, examinamos o efeito do tempo de preservação no comprimento total do corpo e no peso seco de espécimes adultos do cladócero neotropical Ceriodaphnia silvestrii fixados com solução de formalina a $4 \%$. Métodos: A relação entre essas variáveis foi examinada sob efeito crescente do tempo (7, 30 e 60 dias) após a preservação usando modelos lineares e análise de variância. Resultados: O comprimento corporal total não diferiu estatisticamente entre os cladóceros náo-preservados e preservados, enquanto o peso seco foi reduzido com o aumento do tempo de 
preservação, resultando 15, 47 e 57\% de perda de peso, respectivamente. As relaçóes peso-comprimento foram significativamente positivas em todos os tratamentos, embora valores mais elevados tenham sido encontrados em amostras frescas e de 7 dias. Conclusóes: Destacamos que, para Ceriodaphnia silvestrii, o uso da solução de formalina como método de preservação não é adequado quando o principal interesse é a estimativa de biomassa. Recomendamos que as estimativas de peso seco de amostras preservadas sejam feitas o mais rápido possível. Por fim, considerando as perdas atribuídas à preservação e às variações intraespecíficas da biomassa dos organismos, recomenda-se a aplicação de fatores de correção uma vez que amostras preservadas são importantes na avaliação de mudanças de longo prazo nas comunidades biológicas.

Palavras-chave: tamanho corporal; Daphnidae; peso seco; peso fresco; produção secundária.

\section{Introduction}

Biological and ecological studies often require biometrical measurements, biomass calculations or estimates as tools to evaluate community structure. Size per se influences functional and ecological traits of organisms and their role in ecosystem processes (Brown et al., 2004; Woodward et al., 2005). As a result, studying the influence of body size on trophic efficiency has become a prominent focus in ecology and applied biology, emphasizing the need for accurate and efficient individual and population measurements (LaBarbera, 1989; Wetzel et al., 2005; Costa-Paiva et al., 2007; Souza \& Barros, 2017). Most often, measurements are based on dry weight (e.g. Platt et al., 1969; Dumont et al., 1975; Bottrell et al., 1976; Culver et al., 1985), which ideally should be taken on fresh, unpreserved material. However, an immediate sorting of sampled material, as well as any subsequent processing, are almost impossible under field conditions and samples need to be preserved immediately after collection. Thus, qualitative and quantitative measurements are mostly determined from preserved organisms.

Generally, buffered formalin solution and ethanol are considered to be suitable preservatives and have been commonly used as fixative for zooplankton samples and other invertebrate groups (Souza \& Barros, 2017). Nearly one hundred years ago, several studies already described deleterious effects of those preservatives on dry weight of preserved animals (e.g.: Geng, 1925; Omori, 1978; Giguère et al., 1989). Impacts of preservatives on biometrical characteristics of macroinvertebrate fauna is also largely known (Mackay \& Kalff, 1969; Donald \& Paterson, 1977; Wiederholm \& Eriksson, 1977; Maslin \& Pattee, 1981), as well as for being also much less appropriate fixative (e.g. in genetic analysis) than absolute ethanol (Timm \& Martin, 2015). However, studies evaluating the effects of preservation of freshwater zooplankton samples are scarce and most of the published literature comes from temperate regions (e.g. Giguère et al., 1989; Omori, 1978; Pakhomov, 2003). Therefore, considering that methodological studies evaluating the reliability of primary data (e.g. density, composition and biomass) are critical for efficient environmental characterization such as trophic conditions (Sendacz et al., 2006; Klippel et al., 2020), and biomonitoring studies for ecological impact assessment (Leppänen, 2018). Thus, it is a critical step in environmental studies, and its broad objectives, to preserve samples' characteristics as much as possible for more reliable ecological interpretations (Huffman et al., 2020).

Length-weight regressions are one of the most commonly used methods for estimating zooplankton dry weight and biomass (Dumont et al., 1975; Bottrell et al., 1976; McCauley, 1984; Culver et al., 1985). Such analysis allows the assessment of a rather difficult measurement, the dry weight, by using a much easier biological parameter to obtain - the body length - plus applying linear regression equations. These relationships between zooplankton body length and weight are well documented in the literature, being often used in zooplankton studies for dry weight estimations (Blettler \& Bonecker, 2006; Brito et al., 2013). As proposed by Edmondson \& Winberg (1971) and Edmondson (1974), species biomass can be calculated from the average lengths and organisms' densities through formulae relating the dry weights of individuals to their lengths for the main cladocerans species, using the formula $\mathrm{W}=\mathrm{a} \mathrm{L}^{\mathrm{b}}$, where: $\mathrm{W}=$ weight, $\mathrm{a}=$ intercept, $\mathrm{L}=$ length, and $\mathrm{b}=$ slope. However, not all species have their respective specific formula, especially for the Neotropical species. Thus, while lacking specific equations, studies often apply the constants 'a' and 'b' obtained for different species of the same genus (Pace \& Orcutt Junior, 1981; Santos et al., 2010) adding one more relevant confounding factor. Additionally, only few studies have been carried out to estimate dry weight losses due to chemical fixative agents on freshwater zooplankton samples (Omori, 1978). Such gap of 
knowledge regarding preserved samples dry weight variation can drive scientists to misleading lengthweight models as a consequence of not having accurate data. Therefore, it is highly important to assess and quantify such losses among zooplankton representatives in order to provide more reliable models that can also account for losses over the course of preservation time.

Concerning the zooplankton fauna, many are the issues for the direct weighing of individuals and assessing dimensional characters: i) the taxonomic diverse and small-sized taxa, ii) their differential and fragile body structures with variable effects on osmotic balance (Durbin \& Durbin, 1978; Miliou \& Moraitou-Apostolopoulou, 1991) that can be altered by chemical substances such as formaldehyde (Williams \& Robins, 1982), iii) biomass variations related to habitat type, levels of nutrient enrichment and biotic factors such as predation pressure (Tessier et al., 1983; Culver et al., 1985), and iv) continuous reproduction and overlapping cohorts, which is the case of most neotropical species. To overcome these issues, specific methods are used to infer zooplankton production (Winberg, 1971; McCauley, 1984; Harris et al., 2000), including the widely used geometric-based method and the length-weight regressions (e.g., Edmondson \& Winberg, 1971; McCauley, 1984; Castilho-Noll \& Arcifa, 2007; Ghidini \& SantosSilva, 2009. For microcrustaceans (cladocerans and copepods), weight estimates from lengthweight regressions have been the most frequently used technique. Cladocerans are important components of zooplanktonic communities of freshwater ecosystems, and account for almost $45-91 \%$ of the sizable fraction of secondary production (Pederson et al., 1976). In lentic aquatic systems, they occupy a central position within food chains and are important components of zooplankton in temporary and perennial lakes and ponds (Forró et al., 2008; Karuthapandi \& Rao, 2016). Furthermore, due to their short life cycle, predominantly parthenogenetic reproduction rates and intermediate position in lake's food web (Jeppesen et al., 2011), cladoceran species are commonly used as indicators of environmental changes (Kurek et al., 2010; Brasil et al., 2019).

In this study, we evaluated the effect of $4 \%$ formalin solution buffered with sodium tetraborate (borax) on body length and dry weight of the widely spread neotropical cladoceran Ceriodaphnia silvestrii Daday 1902 (Daday, 1902) sampled in a tropical reservoir. We compared the body length and dry weight of fresh-unpreserved and preserved specimens from fixation up to 7,30 and 60 days to test the following hypotheses: i) the negative effect of preservation time with formalin is stronger on dry weight than on body length, and ii) slope differences and low correlations among treatments are expected for length-weight regressions of fixed specimens, being related to preservation time.

\section{Material and Methods}

\subsection{Assay organism: Ceriodaphnia silvestrii Daday 1902 (Daphnidae)}

Locally occurring Ceriodaphnia silvestrii was collected in Ribeirão das Lajes hydroelectric

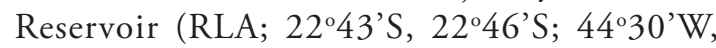
$\left.44^{\circ} 60^{\prime} \mathrm{W}\right)$, an oligotrophic system located in Southeastern Brazil, in Rio de Janeiro state. The reservoir is characterized by low chlorophyll- $a$ and high water temperature, normally above $25^{\circ}$ C (Guarino et al., 2005; Soares et al., 2008; Klippel et al., 2020). Due to these characteristics, the zooplankton community in RLA is composed by small-sized (e.g. Bosmina hagmani $<0.5 \mathrm{~mm}$ ) and medium-sized cladocerans (e.g. C. silvestrii 0.5-1.0mm) (Macêdo et al., 2019). C. silvestrii was selected for three major reasons: i) mediumsized zooplankton species are generally more representative in terms of biomass than smaller ones (e.g. Hanazato, 1998), ii) being Ceriodaphnia a widely spread genus in Brazil (Elmoor-Loureiro, 2000), and iii) C. silvestrii is among the most abundant species in RLA (Macêdo et al., 2019).

\subsection{Sampling and preserving}

Zooplankton samples were collected from the subsurface of the water column (total volume of $100 \mathrm{~L}$ ) in a pelagic zone using graduated bucket (20L), and then filtered using a plankton net $(64 \mu \mathrm{m}$ mesh size). Thus, specimens were sampled once and from the same patch to minimize environmental influence on specimen's morphometry. Half of the samples were immediately preserved in formalin solution (final concentration 4\%) buffered with sodium tetraborate (borax), and the other half was kept fresh and unpreserved (Figure 1). Formalin solution at $4 \%$ concentration was evaluated as it is one of the most commonly employed preservation techniques according to literature (Lincoln \& Sheals, 1979) and has been known to cause changes in both length and weight in an array of organisms and tissues (Souza \& Barros, 2017; Costa et al., 


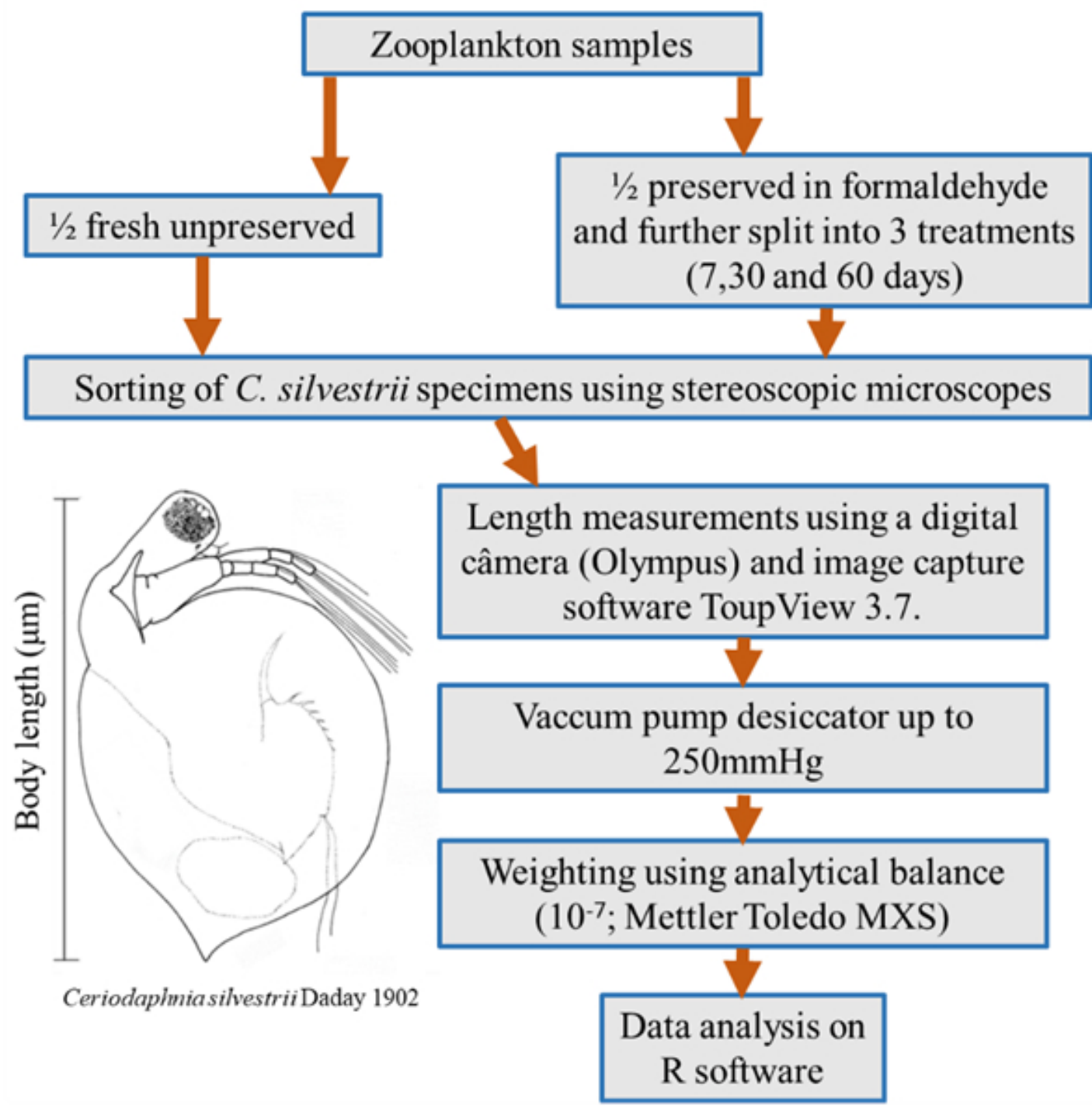

Figure 1. Work flow chart showing the methodological steps of the experimental work.

2021), as well, for being predominantly used for Ceriodaphnia (Table 1).

\subsection{Experimental design}

A total of 840 specimens of $C$. silvestrii were split into four treatments: fresh (unpreserved) and preserved samples submitted to three different preservation times $(7,30$, and 60 days). For each treatment, the specimens $(\mathrm{N}=210)$ were split into seven replicates containing 30 individuals. In the laboratory, intact organisms were carefully identified to the lowest level of taxonomic hierarchy aiming to avoid inter genus-variation, under an optical microscope (Olympus BX-50) at x400 magnification using specific literature (Elmoor-Loureiro, 1997). Eggs and embryos were carefully removed before drying and weighing processes. Specimens' body length measurements were carried for each single individual from anterior margin of head (or crest) to posterior margin of valves (Figure 1) using an optical microscope (Zeiss Olympus BX-50) at $400 \mathrm{x}$ magnification, a digital camera (Olympus), and image capture software ToupView 3.7.

Replicates weighing was done in the laboratory using the following protocol: 30 individuals of each replicate were pooled into a petri dish, dried at $60^{\circ} \mathrm{C}$ for 24 hours, then cooled in a vacuum pump desiccator up to $250 \mathrm{mmHg}$ at room temperature before weighing in an analytical balance $\left(10^{-7}\right.$; Mettler Toledo MX5).

\subsection{Data analysis}

First, we calculated the mean length and weight for each different treatment as individuals 
Table 1. Previous studies using fresh or formalin-preserved specimens of freshwater cladocerans. NM = not mentioned.

\begin{tabular}{lccc}
\hline \multicolumn{1}{c}{ Reference } & preserved or fresh & $\begin{array}{c}\text { preservation } \\
\text { method }\end{array}$ & preservation time \\
\hline Matsumura-Tundisi et al., 1989 & fresh & - & - \\
Mangas \& Garcia, 1991 & preserved & $4 \%$ formalin & NM \\
Nandini et al., 2005 & preserved & $10 \%$ formalin & NM \\
Maia-Barbosa \& Bozelli, 2005 & preserved & $4 \%$ formalin & NM \\
Sendacz et al., 2006 & preserved & $4 \%$ formalin & NM \\
Corgosinho \& Pinto-Coelho, 2006 & preserved & $4 \%$ formalin & NM \\
Bonecker et al., 2007 & preserved & $4 \%$ formalin & NM \\
Guevara et al., 2009 & preserved & $4 \%$ formalin & NM \\
Santos et al., 2010 & preserved & $4 \%$ formalin & NM \\
Bonecker et al., 2011 & preserved & $4 \%$ formalin & $>3$ years \\
Brito et al., 2013 & preserved & $4 \%$ formalin & NM \\
Silva et al., 2014 & preserved & $4 \%$ formalin & about 6 weeks \\
Burgis, 1974 & preserved & $5 \%$ formalin & NM \\
Dumont et al., 1975 & preserved & $4 \%$ formalin & few minutes to several years \\
Irvine \& Waya, 1999 & preserved & $4 \%$ formalin & NM \\
Melão \& Rocha, 2000 & preserved & $4 \%$ formalin & NM \\
Saint-Jean \& Bonou, 1994 & preserved & $5 \%$ formalin & \\
\hline
\end{tabular}

were weighted in groups of 30 and measures were taken individually. To reduce data skewness, we transformed data using $\ln (\mathrm{x})$. Length-weight regressions were carried out using $\mathrm{Y}=\mathrm{a} \mathrm{x}^{\mathrm{b}}$, where $\mathrm{Y}=\ln \mathrm{W}(\mu \mathrm{g}), \mathrm{x}=\ln \mathrm{L}(\mathrm{mm}), \mathrm{a}=$ estimate of intercept, $b=$ estimate of slope (Dumont et al., 1975; Culver et al., 1985). We performed ANOVA to evaluate the differences in length and weight among the different treatments. Further, we evaluated the effect of preservation on the length-weight relationships over time, using one-way analysis of covariance (ANCOVA). Briefly, the main goal was to include the covariate as a statistical control to explain variation on dry weight, reducing the error variation and increasing the statistical power on the underlying treatment. Subsequently, estimated marginal means (EMM) were calculated in order to provide pairwise comparison between slopes. Preliminarily, the following assumptions of ANCOVA were verified: i. independence between independent variable (treatment) and co-variable (length). In other words, body length was not significantly different between treatments (ANOVA, df=3, F=2.73, p=0.066); ii. co-variable and dependent variables showed linear relationship; iii. homoscedasticity of regression parameters was verified by comparing the regression slopes (Levene's test $\mathrm{p}=0.656$ ); iv. residuals followed normal distribution (Shapiro-Wilk test, $\mathrm{p}=0.447$ ). All analyses were performed in $\mathrm{R} 4.0 .1$ ( $\mathrm{R}$ Core Team, 2020) and plots were made using ggplot2 (Wickham, 2016).

\section{Results}

Preservation negatively affected both length and dry weight measurements of Ceriodaphnia silvestrii (Figure 2). Organisms from fresh samples were smaller than those from preserved treatments (ANOVA df $=3, F=2.73, p=0.066$ ), however, they accounted for higher values of dry weight (ANOVA $\mathrm{gl}=3, \mathrm{~F}=64.772, \mathrm{p}<0.001$ ) (Figure 2). The increase in body length after the fresh period and its subsequent decrease in the following treatments was not statistically significant. Differently, dry weight significantly decreased as preservation time increased. Mean dry weight decreased by $15.96 \%$ after seven days. Much of the weight loss occurred after 30 days with a decrease of $47.28 \%$ (Figure 2a). Afterwards, the highest loss percentage along two months reached $56.92 \%$, the maximum loss.

The linear models between fresh and preserved length-weight relationships showed significant p-values (Table 2). However, the $\mathrm{R}^{2}$ of fresh (0.66) and seven days (0.59) models were higher than those from $30(0.36)$ and $60(0.41)$ days.

The covariate, preservation time (treatment), was significantly related to the dry weight, $F(3,23)$ $=161.1, \mathrm{p}<.001$. There was also a significant effect of the length of the specimens on the dry weight after controlling for the effect of the treatment $F$ $(1,23)=23.2, \mathrm{p}<0.001$.

Slopes were significantly different (Table 3 ), so treatment has a significant effect on the dependent variable which in this case can be interpreted as a significant difference in 'intercepts' between the 


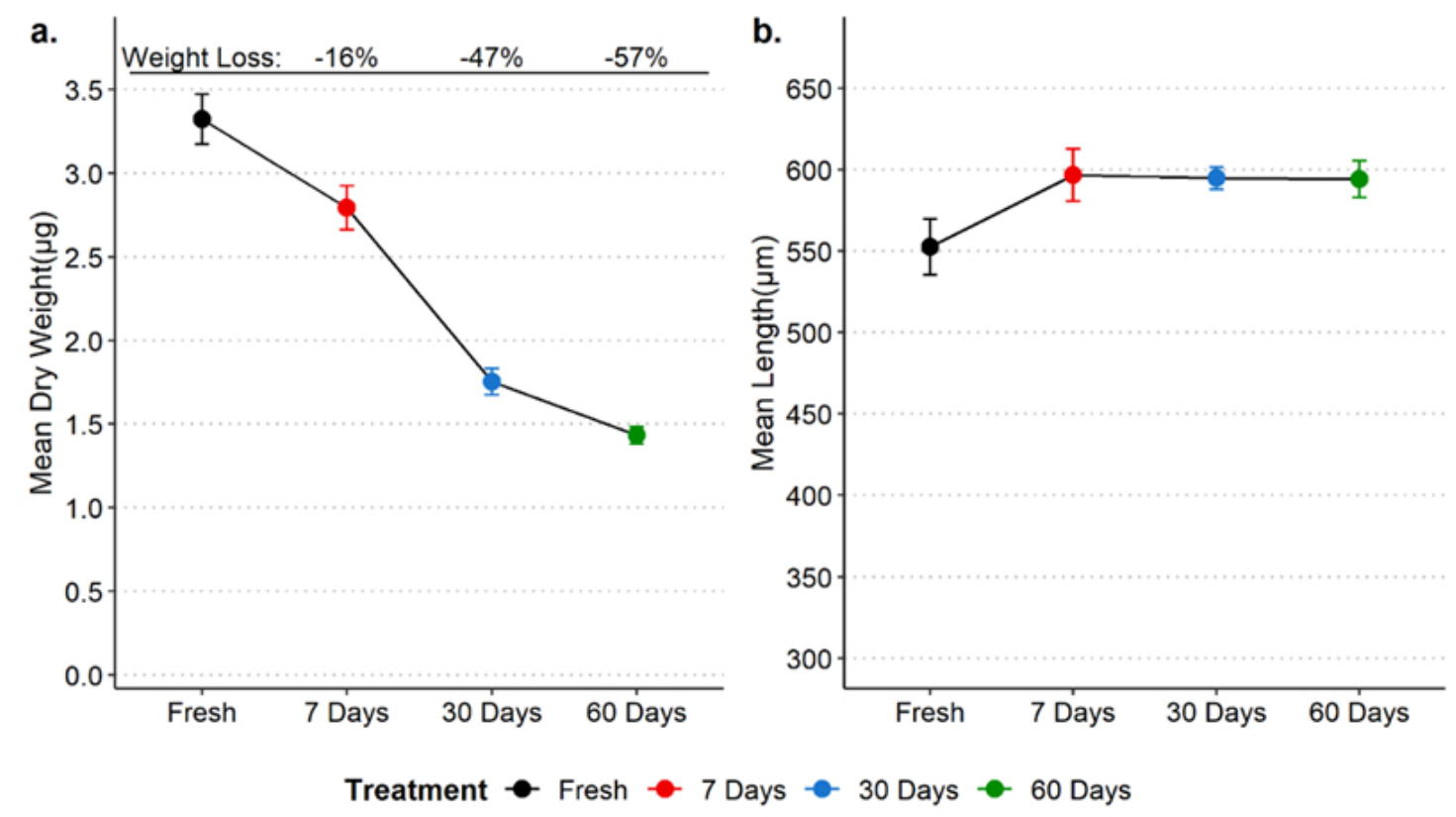

Figure 2. Mean and standard error of dry weight (a.) and body length (b.) by treatments.

Table 2. Regression coefficients for dry weight-length relationships in the different treatments (fixation time).

\begin{tabular}{ccccc}
\hline & \multicolumn{3}{c}{$\mathbf{L n}(\mathbf{y}) \mathbf{=} \mathbf{a}+\mathbf{b} \boldsymbol{\operatorname { l n }}(\mathbf{x})$} & \multirow{2}{*}{$\mathbf{p}$-value } \\
\cline { 2 - 4 } & $\mathbf{a}$ & $\mathbf{b}$ & $\mathbf{R}^{2}$ & $0.02\left(^{*}\right)$ \\
\hline Fresh & -6.494 & 1.218 & 0.66 & $0.03\left(^{*}\right)$ \\
7 days & -7.836 & 1.385 & 0.59 & $0.02\left(^{*}\right)$ \\
30 days & -14.126 & 2.298 & 0.36 & $0.01\left(^{* *}\right)$ \\
60 days & -7.189 & 1.181 & 0.41 & \\
\hline
\end{tabular}

Table 3. ANCOVA pairwise comparison of slopes by groups (treatments) using Tukey's post-hoc test.

\begin{tabular}{ccccc}
\hline Group 1 & Group 2 & df & F & p \\
\hline Fresh & 7 Days & 23 & 5.66 & $\mathrm{p}<0.001\left(^{*}\right)$ \\
Fresh & 30 Days & 23 & 15.12 & $\mathrm{p}<0.001\left(^{*}\right)$ \\
Fresh & 60 Days & 23 & 19.24 & $\mathrm{p}<0.001\left(^{*}\right)$ \\
7 Days & 30 Days & 23 & 10.47 & $\mathrm{p}<0.001\left(^{*}\right)$ \\
7 Days & 60 Days & 23 & 14.93 & $\mathrm{p}<0.001\left(^{*}\right)$ \\
30 Days & 60 Days & 23 & 4.47 & $\mathrm{p}<0.001\left(^{*}\right)$ \\
\hline
\end{tabular}

*Significant p-values.

regression lines of treatments (fresh, 7, 30 and 60 days).

Despite the sustained relationship between length and dry weight in all treatments (Table 2), preserved samples showed lower predicted values for dry weight (Figure 3). Post hoc (Tukey) analysis underlined pairwise differences in length-weight regression among all treatments (Table 3).

\section{Discussion}

Length-weight regressions have been frequently used to estimate the individual biomass of cladocerans size classes (Edmondson \& Winberg, 1971; Blettler \& Bonecker, 2006). Similarly, length significantly predicts dry weight values, independently of the preservation time. More interesting is that when the effect of length is removed, the effect of preservation time becomes significant on dry weight of Ceriodaphnia silvestrii. Despite these findings, herein, we do not advocate for the elimination of chemical preservation in ecological studies, since it is considered the most suitable and convenient method in the field. Moreover, due to their small size, counting and 


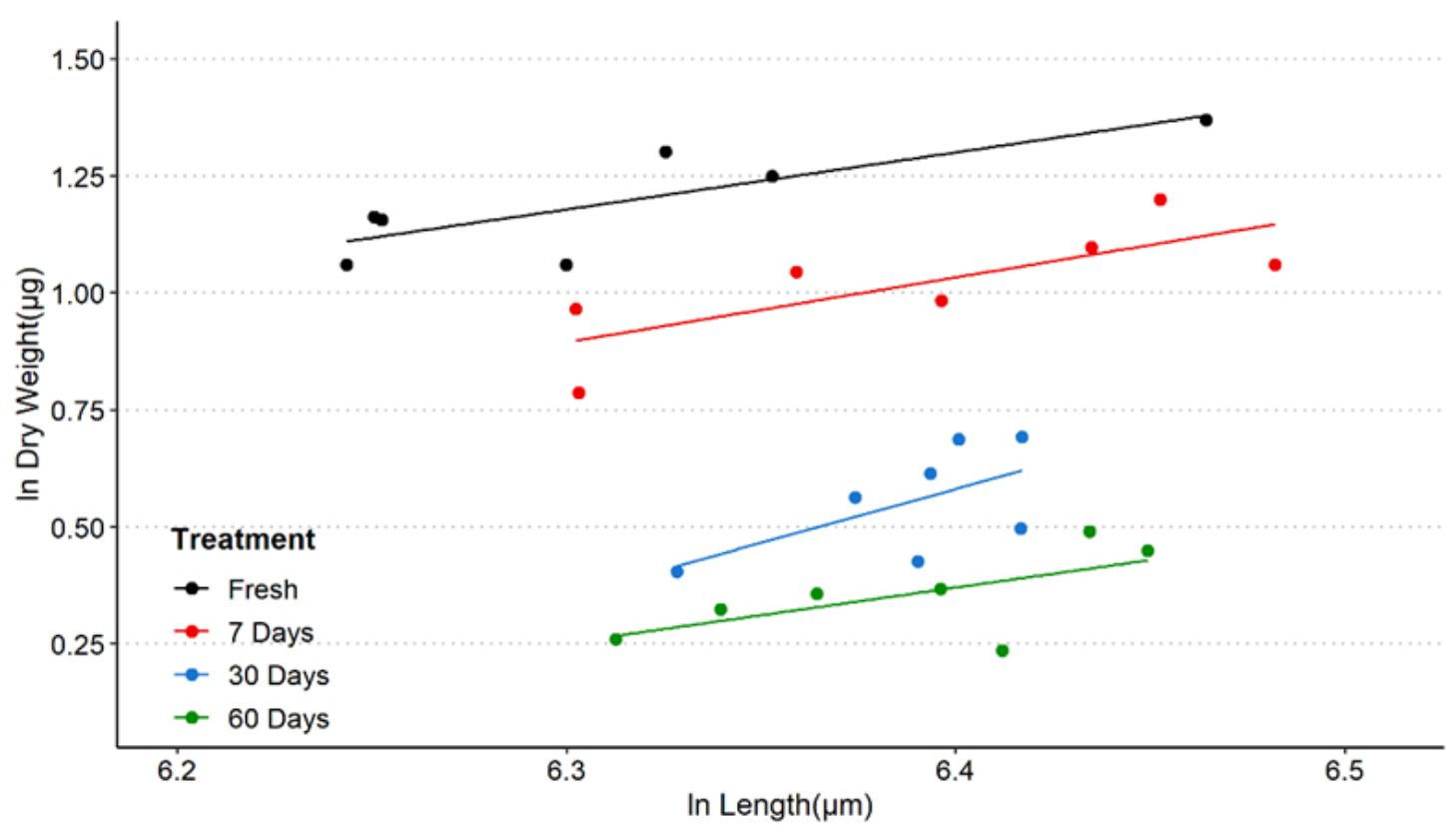

Figure 3. Scatterplot of dry weight (response variable) against body length (the covariate variable), on the experimental treatments.

measuring zooplankters are time-consuming and require undamaged specimens which can be easily solved by preservation.

In general, the range of variations in length was similar among treatments, however, fresh animals were smaller but also accounted for higher dry weight values (Figure 2, Table 2). Additionally, samples with more than 60 days of preservation showed more than $50 \%$ of dry weight loss. The weight losses through a short-term experiment (Figure 2) generates concern as it may represent a great loss of information for both water quality monitoring and ecological studies assessing the secondary production, which may mislead results associated with these organisms (Pederson et al., 1976; Arcifa, 1984). Moreover, cladocerans are important representatives of planktonic and benthic freshwater communities, being the species of Daphnia and Ceriodaphnia valuable indicators of water quality conditions and ecosystem functioning (ABNT, 2005; Pakrashi et al., 2013; Mansano et al., 2018) accounting for $45-91 \%$ of the sizable fraction of secondary production (Pederson et al., 1976).

The regressions between length and dry weight were different between treatments (Tables 2 and 3). This difference in allometric growth manifested itself as a different slope in all four regression lines. The interaction is significantly different meaning that the effect of the continuous covariate (length) on the response (dry weight) depends on the level of the categorical factor (preservation time). Also, 30- and 60-days treatments showed higher residuals and therefore, smaller $\mathrm{R}^{2}$ values, whereas fresh and 7 days treatments indicated higher $\mathrm{R}^{2}$ values when compared to the aforementioned treatments. Such discrepancies indicate that the relationship between body length and dry weight weakens with longer preservation times.

Our assay organism is a filtering herbivore widely known to feed on micro algae in freshwaters. As expected, our populations showed lower values of length and consequently dry weight, comparatively to other systems with higher trophic state and thus, theoretically, with more resource availability. Further, cultivated organisms also showed higher dimensions as they have constant input of good quality food and much less biotic and abiotic stress compared to natural habitats. In this regard, the experimental findings allied to a literature review on biometrical measurements of C. silvestrii (see Table 1), suggest that estimates of biomass and production of aquatic invertebrates are often done without compensation for losses in dry weight and are certainly underestimated. Predicted weights from non-specific regressions also include an error factor since regression parameters (body length and dry weight) are sensible to habitat types, temperature, food type and availability (Michaloudi, 2005). Moreover, the sensibility of body length and dry weight may vary among 
individuals of the same species (Dumont et al., 1975; Bottrell et al., 1976). Therefore, it is suggested that the body length of $C$. silvestrii and other tropical cladocerans from preserved samples can be used as a measure for the calculation of biomass from the length-weight relationship if weight loss is taken into consideration.

Dry weight measurements followed the expected pattern, decreasing along with preservation time. Accordingly, deleterious effects of preservation time were found on body length and dry weight relationship as $C$. silvestrii (Table 2 and 3 ) size has a significant and positive effect on the dry weight. In this sense, $4 \%$ formaldehyde (final concentration) in the first two months affected significantly mainly the dry weight of zooplankton organisms. As zooplankton weight and length are largely used to estimate production in aquatic ecosystems, our results indicate that interpretations on zooplankton secondary productivity based on those variables determined from samples preserved for extended periods of time may be greatly misleading.

Previously performed experimental studies evaluating sample preservation time alongside this study showed an underestimate of biomass quantification, but also contradictory results for body size alterations through time, showing the need of a standardization of preservation periods for the ecological analysis aiming reproducibility. Nonetheless, assessments of formalin effects on quantitative data for neotropical fauna are scarce, and despite require laborious laboratory work and taxonomic resolution effort our study advocate to future researches to restore this debate. We also suggest, different substances for evaluating the effects of preservation of different taxonomic groups of zooplankton and their development stages. Also, studies considering longer preservation periods are advised to match the average time lapse between preservation and biomass estimations. Accordingly, we also suggest studies in other regions since the local features of the watersheds regarding soil composition and inorganic components may be different between these regions (StefanelliSilva et al., 2019; Klippel et al., 2020) and may affect preservative solutions.

\section{Acknowledgements}

This study was financed in part by the Coordenação de Aperfeiçoamento de Pessoal de Nível Superior-Brasil (CAPES); Finance Code 001. The authors would like to thank the Graduate Course in Neotropical Biodiversity (PPGBIO-
UNIRIO). We would like to thank LMA ElmoorLoureiro for providing the specimen illustration for this work.

\section{References}

ARCIFA, M.S. Zooplankton composition of ten reservoirs in Southern Brazil. Hydrobiologia, 1984, 113(1), 137-145. http://dx.doi.org/10.1007/ BF00026600.

ASSOCIAÇÃO BRASILEIRA DE NORMAS TÉCNICAS - ABNT. NBR 13373: Ecotoxicologia aquática - Toxicidade crônica: Métodos de ensaio com Ceriodaphnia spp (Crustáceo, Cladocera). Rio de Janeiro: ABNT, 2005.

BLETTLER, M.C.M. and BONECKER, C.C. Avaliação da biomassa de microcrustáceos em ambientes aquáticos continentais. Interciencia, 2006, 31, 591-597.

BONECKER, C.C., AZEVEDO, F. and SIMÕES, N.R. Zooplankton body-size structure and biomass in tropical floodplain lakes: relationship with planktivorous fishes. Acta Limnologica Brasiliensia, 2011, 23(3), 217-228. http://dx.doi.org/10.1590/ S2179-975X2012005000005.

BONECKER, C.C., NAGAE, M.Y., BLETLLER, M.C.M., VELHO, L.F.M. and LANSAC-TÔHA, F.A. Zooplankton biomass in tropical reservoirs in southern Brazil. Hydrobiologia, 2007, 579(1), 115123. http://dx.doi.org/10.1007/s10750-006-0391-x.

BOTTRELL, H.H., DUNCAN, A., GLIWICZ, Z.M., GRYGIEREK, E., HERZIG, A., HILLBRICHTILKOWSKA, A., KURASAWA, H., LARSSON, P. and WEGLENSKA, T. A Review of some problems in zooplankton production studies. Norwegian Journal of Zoology, 1976, 24(24), 419-456.

BRASIL, L.S., LUIZA-ANDRADE, A., KISAKA, T.B., ILHA, P. and SOUSA, F.D.R. Cladocera distribution along an environmental gradient on the Cerrado-Amazon ecotone: a preliminary study. Acta Limnologica Brasiliensia, 2019, 31, e29. http://dx.doi. org/10.1590/s2179-975×2919.

BRITO, S.L., MAIA-BARBOSA, P.M. and PINTOCOELHO, R.M. Length-weight relationships and biomass of the main microcrustacean species of two large tropical reservoirs in Brazil. Brazilian Journal of Biology = Revista Brasileira de Biologia, 2013, 73(3), 593-604. http://dx.doi.org/10.1590/S151969842013000300017. PMid:24212700.

BROWN, J.H., GILLOOLY, J.F., ALLEN, A.P., SAVAGE, V.M. and WEST, G.B. Toward a metabolic theory of ecology. Ecology, 2004, 85(7), 1771-1789. http://dx.doi.org/10.1890/03-9000.

BURGIS, M.J. Revised estimates for the biomass and production of zooplankton in Lake George, Uganda. Freshwater Biology, 1974, 4(6), 535-541. http:// dx.doi.org/10.1111/j.1365-2427.1974.tb00113.x. 
CASTILHO-NOLL, M.S. and ARCIFA, M.S. Lengthweight relationships for zooplanktonic species of a tropical Brazilian lake: Lake Monte Alegre. Acta Limnologica Brasiliensia, 2007, 9, 93-100.

CORGOSINHO, P.H.C. and PINTO-COELHO, R.M. Zooplankton biomass, abundance and allometric patterns along an eutrophic gradient at Furnas Reservoir (Minas Gerais, Brazil). Acta Limnologica Brasiliensia, 2006, 18(2), 213-224.

COSTA, A.B., SILVA, M.B., FRAGA, R.E., ROCHA, A.A., NISHIYAMA, P.B., ANJOS, M.S., BUCHAIM, J.J.S. and ROCHA, M.A. Evaluation of an alternative technique for preserving crustaceans in dry conditions with joint mobility: a proposal for didactic purposes. Acta Scientiarum. Biological Sciences, 2021, 43(1), e53450. http://dx.doi. org/10.4025/actascibiolsci.v43i1.53450.

COSTA-PAIVA, E.M., PAIVA, P.C. and KLAUTAU, M. Anaesthetization and fixation effects on the morphology of Sabellid polychaetes (Annelida: Polychaeta: Sabellidae). Journal of the Marine Biological Association of the United Kingdom, 2007, 87(5), 1127-1132. http://dx.doi.org/10.1017/ S002531540705223X.

CULVER, D.A., BOUCHERLE, M.M., BEAN, D.J. and FLETCHER, J.W. Biomass of freshwater crustacean zooplankton from length-weight regressions. Canadian Journal of Fisheries and Aquatic Sciences, 1985, 42(8), 1380-1390. http://dx.doi. org/10.1139/f85-173.

DADAY, E.V. Mikroskopische süsswasserthiere aus patagonien, gesammelt von Dr. Filippo Silvestri. Természetrajzi Füzetek, 1902, 25, 201-310.

DONALD, G.L. and PATERSON, C.G. Effect of preservation on wet weight biomass of chironomid larvae. Hydrobiologia, 1977, 53(1), 75-80. http:// dx.doi.org/10.1007/BF00021235.

DUMONT, H.J., VAN DE VELDE, I. and DUMONT, $S$. The dry weight estimate of biomass in a selection of Cladocera, Copepoda and Rotifera from the plankton, periphyton and benthos of continental waters. Oecologia, 1975, 19(1), 75-97. http://dx.doi. org/10.1007/BF00377592. PMid:28308833.

DURBIN, E.G. and DURBIN, A.G. Length and weight relationships of Acartia clausi from Narragansett Bay, R.I. Limnology and Oceanography, 1978, 23(5), 958969. http://dx.doi.org/10.4319/lo.1978.23.5.0958.

EDMONDSON, W.T. and WINBERG, G.G. A manual on methods for the assessment of secondary productivity in fresh waters. Oxford: IBP Handbook, 1971, 358 p.

EDMONDSON, W.T. Secondary production. Verhandlungen des Internationalen Verein Limnologie., 1974, 20, 229-272.

ELMOOR-LOUREIRO, L.M.A. Brazilian cladoceran studies: where do we stand? Nauplius, 2000, 8(1), 117-131.
ELMOOR-LOUREIRO, L.M.A. Identificação de Cladóceros Límnicos do Brasil. Brasília: Editora Universa UCB, 1997

FORRÓ, L., KOROVCHINSKY, N.M., KOTOV, A.A. and PETRUSEK, A. Global diversity of cladocerans (Cladocera; Crustacea) in freshwater. Hydrobiologia, 2008, 595(1), 177-184. http://dx.doi.org/10.1007/ s10750-007-9013-5.

GENG, H. Der futterwert der nat urlichen fischnahrung. Zeit. fur Fischerei, 1925, 23, 137-165.

GHIDINI, A.R. and SANTOS-SILVA, E.N. Biomassa de quatro espécies de Cladocera (Crustacea: Branchiopoda) e sua variaçáo nictemeral no Lago Tupé, Amazonas, Brasil. In: E.N. SANTOS-SILVA, ed. Biotupé: Meio Físico, Diversidade Biológica e Sociocultural do Baixo Rio Negro, Amazônia Central Manaus. Manaus: UEA Ediçôes, 2009, pp. 53-62.

GIGUÈRE, L.A., ST-PIERRE, J.F., BERNIER, B., VEZINA, A. and RONDEAU, J.G. Can we estimate the true weight of zooplankton samples after chemical preservation? Canadian Journal of Fisheries and Aquatic Sciences, 1989, 46(3), 522-527. http:// dx.doi.org/10.1139/f89-070.

GUARINO, A.W.S., BRANCO, C.W.C., DINIZ, G.P. and ROCHA, R. Limnological characteristics of an old tropical reservoir (Ribeirão das Lajes Reservoir, RJ, Brazil). Water, 2005, 17(2), 129-141.

GUEVARA, G., LOZANO, P., REINOSO, G. and VILLA, F. Horizontal and seasonal patterns of tropical zooplankton from the eutrophic Prado Reservoir (Colombia). Limnologica, 2009, 39(2), 128-139. http://dx.doi.org/10.1016/j.limno.2008.03.001.

HANAZATO, T. Response of a zooplankton community to insecticide application in experimental ponds: a review and the implications of the effects of chemicals on the structure and functioning of freshwater communities. Environmental Pollution, 1998, 101(3), 361-373. http://dx.doi.org/10.1016/ S0269-7491(98)00053-0.

HARRIS, R.P., WIEBE, P.H., LOPEZ, J., SKJOLDAL, H.R. and HUNTLEY. M. Ices Zooplankton Methodology Manual. London: Academic Press, 2000.

HUFFMAN, W.W., DAM, H., MASON, R. and BAUMANN, Z. Formalin-preserved zooplankton are not reliable for historical reconstructions of methylmercury bioaccumulation. The Science of the Total Environment, 2020, 738, 139803. http:// dx.doi.org/10.1016/j.scitotenv.2020.139803. PMid:32563789.

IRVINE, K. and WAYA, R. Spatial and temporal patterns of zooplankton standing biomass and production in Lake Malawi. In: O.V. LINDQVIST, H. MÖLSÄ, K. SALONEN and J. SARVALA, ed. From Limnology to Fisheries: Lake Tanganyika and other large lakes. Dordrecht: Springer, 1999, pp. 191-205. http:// dx.doi.org/10.1007/978-94-017-1622-2_18

JEPPESEN, E., NÓGES, P., DAVIDSON, T.A., HABERMAN, J., NÓGES, T., BLANK, K., 
LAURIDSEN, T.L., SØNDERGAARD, M., SAYER, C., LAUGASTE, R., JOHANSSON, L.S., BJERRING, R. and AMSINCK, S.L. Zooplankton as indicators in lakes: a scientific-based plea for including zooplankton in the ecological quality assessment of lakes according to the European Water Framework Directive (WFD). Hydrobiologia, 2011, 676(1), 279-297. http://dx.doi.org/10.1007/s10750011-0831-0.

KARUTHAPANDI, M. and RAO, D.V. Cladoceran diversity, distribution and ecological significance. In: A.K. CHAKRAVARTHY and S. SRIDHARA, ed. Arthropod diversity and conservation in the tropics and sub-tropics. Singapore: Springer, 2016, pp. 183-196. http://dx.doi.org/10.1007/978-981-10-1518-2_11.

KLIPPEL, G., MACÊDO, R.L. and BRANCO, C.W.C. Comparison of different trophic state indices applied to tropical reservoirs. Lakes \& Reservoirs: Science, Policy and Management for Sustainable Use, 2020, 25(2), 214-229. http://dx.doi.org/10.1111/ lre. 12320.

KUREK, J., KOROSI, J.B., JEZIORSKI, A. and SMOL, J.P. Establishing reliable minimum count sizes for cladoceran subfossils sampled from lake sediments. Journal of Paleolimnology, 2010, 44(2), 603-612. http://dx.doi.org/10.1007/s10933-0109440-6.

LABARBERA, M. Analyzing body size as a factor in ecology and evolution. Annual Review of Ecology and Systematics, 1989, 20(1), 97-117. http://dx.doi. org/10.1146/annurev.es.20.110189.000525.

LEPPÄNEN, J.J. An overview of Cladoceran studies conducted in mine water impacted lakes. International Aquatic Research., 2018, 10(3), 207-221. http:// dx.doi.org/10.1007/s40071-018-0204-7.

LINCOLN, R.J. and SHEALS, G.J. Invertebrate animals: collection and preservation. London: Cambridge University Press, 1979. http://dx.doi.org/10.5962/ bhl.title.138449.

MACÊDO, R.L., LOPES, V.G., KOZLOWSKYSUZUKI, B. and BRANCO, C.W.C. Zooplankton community attributes in an oligo-mesotrophic reservoir: a comparative study of two sampling strategies. Anais da Academia Brasileira de Ciências, 2019, 91(1), e20170807. PMid:30569965.

MACKAY, R.J. and KALFF, J. Seasonal variation in standing crop and species diversity of insect communities in a small Quebec stream. Ecology, 1969, 50(1), 101-109. http://dx.doi.org/10.2307/1934667.

MAIA-BARBOSA, P.M. and BOZELLI, R.L. Lengthweight relationships for five cladoceran species in an Amazonian lake. Brazilian Archives of Biology and Technology, 2005, 48(2), 303-308. http://dx.doi. org/10.1590/S1516-89132005000200018.

MANGAS, E. and GARCIA, H. Seasonal fluctuations of zooplankton biomass in Lake Xolotlán (Managua). Hydrological Bulletin, 1991, 25(2), 157-162. http:// dx.doi.org/10.1007/BF02291248.
MANSANO, A.S., SOUZA, J.P., CANCINOBERNARDI, J., VENTURINI, F.P., MARANGONI, V.S. and ZUCOLOTTO, $\mathrm{V}$. Toxicity of copper oxide nanoparticles to Neotropical species Ceriodaphnia silvestrii and Hyphessobrycon eques. Environmental Pollution, 2018, 243(Pt A), 723-733. http://dx.doi.org/10.1016/j. envpol.2018.09.020. PMid:30228063.

MASLIN, J.L. and PATTEE, E. La production du peuplement benthique d'une petite rivière: son évaluation par la méthode de Hynes, Coleman et Hamilton. Archiv für Hydrobiologie, 1981, 92, 321-345.

MATSUMURA-TUNDISI, T., RIETZLER, A. and TUNDISI, J.G. Biomass (dry weight and carbon content) of plankton crustacea from Broa reservoir (São Carlos, SP. - Brazil) and its fluctuation across one year. Hydrobiologia, 1989, 179(3), 229-236. http://dx.doi.org/10.1007/BF00006636.

MCCAULEY, E. The estimation of abundance and biomass of zooplankton in samples. In: J.A. DOWNING and F. RIGLER, ed. Manual of methods for the assessment of secondary productivity in fresh waters. Oxford: Blackwell Scientific Publications, 1984 , pp. 228-265.

MELÁO, M.G.G. and ROCHA, O. Productivity of zooplankton in a tropical oligotrophic reservoir over short periods of time. SIL Proceedings, 2000, 27, 2879-2887.

MICHALOUDI, E. Dry weights of the Zooplankton of Lake Mikri Prespa (Macedonia, Greece). Belgian Journal of Zoology, 2005, 135(2), 223-227.

M I L I O U, H. and M O RA I T O U APOSTOLOPOUlOU, M. Combined effects of temperature and salinity on the population dynamics of Tisbe holothuriae Humes (Copepoda: Harpacticoida). Archiv für Hydrobiologie, 1991, 121, 431-448.

NANDINI, S., SARMA, S.S.S. and RAMÍREZGARCÍA, P. Length-weight relationships of three cladoceran species from a tropical reservoir in Mexico. Journal of Freshwater Ecology, 2005, 20(2), 405-406. http://dx.doi.org/10.1080/02705060.20 05.9664981.

OMORI, M. Some factors affecting dry weight, organic weight and concentration of carbon and nitrogen in freshly prepared and in preserved zooplankton. Internationale Revue der Gesamten Hydrobiologie, 1978, 63(2), 261-269. http://dx.doi.org/10.1002/ iroh. 19780630211.

PACE, L.M. and ORCUTT JUNIOR, J.D.J.R. The relative importance of protozoans, rotifers, and crustaceans in a freshwater zooplankton community. Limnology and Oceanography, 1981, 26(5), 822-830. http://dx.doi.org/10.4319/lo.1981.26.5.0822.

PAKHOMOV, E.A. Correction of zooplankton and benthos biomass underestimations from 
formaldehyde-preserved samples. Archiv für Fischereiund Meeresforschung, 2003, 50, 141-148.

PAKRASHI, S., DALAI, S., HUMAYUN, A., CHAKRAVARTY, S., CHANDRASEKARAN, N. and MUKHERJEE, A. Ceriodaphnia dubia as a potential bio-indicator for assessing acute aluminum oxide nanoparticle toxicity in fresh water environment. PLoS One, 2013, 8(9), e74003. http://dx.doi.org/10.1371/journal.pone.0074003. PMid:24040143.

PEDERSON, G.L., WELCH, E.B. and LITT, A.H. Plankton secondary productivity and biomass: their relation to lake trophic state. Hydrobiologia, 1976, 50(2), 129-144. http://dx.doi.org/10.1007/ BF00019816.

PLATT, T., BRAWN, V.W. and IRWIN, B. Calorific and carbon equivalents of zooplankton biomass. Journal of the Fisheries Research Board of Canada, 1969, 26(9), 2345-2349. http://dx.doi.org/10.1139/f69-228.

R CORE TEAM. R: A language and environment for statistical computing [online]. Vienna: R Foundation for Statistical Computing, 2020 [viewed 23 Sep. 2020]. Available from: https://www.R-project.org/.

SAINT-JEAN, L. and BONOU, S.J. Growth, production, and demography of Moina micrura in brackish tropical fishponds (Layo, Ivory Coast). Hydrobiologia, 1994, 272(1-3), 125-146. http:// dx.doi.org/10.1007/BF00006517.

SANTOS, R.M., NEGREIROS, N.F., SILVA, L.C., ROCHA, O. and SANTOS-WISNIEWSKI, M.J. Biomass and production of Cladocera in Furnas Reservoir, Minas Gerais, Brazil. Brazilian Journal of Biology = Revista Brasileira de Biologia, 2010, 70, 879-887, 3 Supplement. http://dx.doi.org/10.1590/ S1519-69842010000400019. PMid:21085793.

SENDACZ, S., CALEFFI, S. and SANTOS-SOARES, J. Zooplankton biomass of reservoirs in different trophic conditions in the State of São Paulo, Brazil. Brazilian Journal of Biology = Revista Brasileira de Biologia, 2006, 66(1B), 337-350. http:// dx.doi.org/10.1590/S1519-69842006000200016. PMid:16710526.

SILVA, L.H.S., HUSZAR, V.L.M., MARINHO, M.M., RANGEL, L.M., BRASIL, J., DOMINGUES, C.D., BRANCO, C.C. and ROLAND, F. Drivers of phytoplankton, bacterioplankton, and zooplankton carbon biomass in tropical hydroelectric reservoirs. Limnologica, 2014, 48, 1-10. http://dx.doi. org/10.1016/j.limno.2014.04.004.

SOARES, M.C.S., MARINHO, M.M., HUSZAR, V.L.M., BRANCO, C.W.C. and AZEVEDO, S.M.F.O. The effects of water retention time and watershed features on the limnology of two tropical reservoirs in Brazil. Lakes and Reservoirs: Research and Management, 2008, 13(4), 257-269. http://dx.doi. org/10.1111/j.1440-1770.2008.00379.x.
SOUZA, G.B.G. and BARROS, F. Cost/benefit and the effect of sample preservation procedures on quantitative patterns in benthic ecology. Helgoland Marine Research, 2017, 71(1), 21. http://dx.doi. org/10.1186/s10152-017-0501-3.

STEFANELLI-SILVA, G., ZUANON, J. and PIRES, T. Revisiting Amazonian water types: experimental evidence highlights the importance of forest stream hydrochemistry in shaping adaptation in a fish species. Hydrobiologia, 2019, 830(1), 151-160. http://dx.doi.org/10.1007/s10750-018-3860-0.

TESSIER, A.J., HENRY, L.L., GOULDEN, C.E. and DURAND, M.W. Starvation in Daphnia: energy reserves and reproductive allocation. Limnology and Oceanography, 1983, 28(4), 667-676. http://dx.doi. org/10.4319/lo.1983.28.4.0667.

TIMM, T. and MARTIN, P.J. Clitellata: Oligochaeta. In: J. THORP and D.C. ROGERS, ed. Ecology and general biology: Thorp and Covich's freshwater invertebrates. Cambridge: Academic Press, 2015, pp. 529-549. http://dx.doi.org/10.1016/B978-012-385026-3.00021-8.

WETZEL, M.A., LEUCHS, H. and KOOP, J.H.E. Preservation effects on wet weight, dry weight, and ash-free dry weight biomass estimates of four common estuarine macro-invertebrates: no difference between ethanol and formalin. Helgoland Marine Research, 2005, 59(3), 206-213. http://dx.doi. org/10.1007/s10152-005-0220-z.

WICKHAM, H. Ggplot2: elegant graphics for data analysis. New York: Springer-Verlag, 2016 [viewed 30 Apr. 2021]. Available from: https://ggplot2. tidyverse.org

WIEDERHOLM, T. and ERIKSSON, L. Effects of alcohol-preservation on the weight of some benthic invertebrates. Zoon, 1977, 5, 29-31.

WILLIAMS, R. and ROBINS, D.B. Effects of preservation on wet weight, dry weight, nitrogen and carbon contents of Calanus helgolandicus. Marine Biology, 1982, 71(3), 271-281. http://dx.doi. org/10.1007/BF00397044.

WINBERG, G.G. Methods for the estimation of production of aquatic animals. London: Academic Press, 1971.

WOODWARD, G., EBENMAN, B., EMMERSON, M., MONTOYA, J.M., OLESEN, J.M., VALIDO, A. and WARREN, P.H. Body size in ecological networks. Trends in Ecology \& Evolution, 2005, 20(7), 402-409. http://dx.doi.org/10.1016/j. tree.2005.04.005. PMid:16701403.

Received: 30 April 2021 Accepted: 26 September 2021

Associate Editor: Priscilla de Carvalho. 